\title{
7. Gang Talk and Strategic Moralisations in Danish Drug Policy Discourses on Young and Recreational Drug Users
}

Thomas Friis Søgaard \& Frank Søgaard Nielsen

\section{Introduction}

While Canada, Uruguay and several US states have legalised cannabis in recent years, and many European countries have implemented or are considering decriminalisation as an option, Denmark is one of the few Western countries that seems to be going in the opposite direction, away from a lenient decriminalisation policy and towards a more restrictive approach (Moeller 2020). In 2004, Denmark introduced a new drug policy that marked the end of a 35 -year period during which possession of illicit drugs had been depenalised, meaning that although it was illegal to possess drugs, in most cases the police refrained from bringing charges for possession for personal use (Frank 2008). In government white papers and in political discourse, the novel and more restrictive approach was called a zero-tolerance policy on drugs, and it was accompanied by a legislative change, which meant that possession of illicit drugs should now always be punished with at least a fine, except in certain specific cases (Houborg 2010). Research has documented how this shift in drug policy was underpinned by a change in governmental rationalities from a 'welfarist' to a more 'neo-liberal/conservative' rationality (Houborg \& Bjerge 20II), and by discursive changes in the way young people, youth culture and drugs were problematised in government reports, policy documents and in the public media (Houborg 2008, 2010; Houborg, Søgaard \& Mogensen 2020). Until the early I990s,

How to cite this book chapter:

Søgaard, Thomas Friis and Nielsen, Frank Søgaard. Gang Talk and Strategic Moralisations in Danish Drug Policy Discourses on Young and Recreational Drug Users. In: Retreat or Entrenchment? Drug Policies in the Nordic Countries at a Crossroads, edited by Henrik Tham, I6I-I8I. Stockholm: Stockholm University Press, 202I. DOI: https://doi.org/Io.I6993/bbo.g. License: CC BY 4.०. 
youth drug use was largely framed as a social problem and seen as a symptom of structural social problems, but from the early $2000 \mathrm{~s}$ it became increasingly associated with nightlife revelling and was depicted as a result of deviant consumer choices (Houborg 20IO). Houborg, Søgaard and Mogensen (2020) thus argue that the repenalisation of drug use in Denmark was intimately coupled with a discursive reconstitution of the young drug user in neo-liberal (autonomous, rational, self-responsible) and neo-conservative (morally compromised) terms.

In this chapter, we wish to build on and add to this previous research on drug policy changes and associated discursive 'framings' (Rein \& Schön I993) of the youth drug use 'problem' in Denmark. It has been well documented how the discursive framing of youth drug use as a deviant consumer choice set within the context of a particular risk environment - i.e. nightlife - became the catalyst for more restrictive policies in Denmark during the early 2000s. In this chapter, however, we analyse the emergence of a new discursive and politically potent framing of youth and recreational drug use. More specifically, we describe how recent years have seen a shift in Danish drug control policy debates, whereby young and recreational drug users are no longer merely framed as consumers of drugs and as wilful lawbreakers but increasingly also as customers in a criminal market, and hence as the market basis for organised crime.

We argue that this policy discourse, depicting young drug users as customers feeding a criminal market, involves a novel 'strategic moralisation' (O’Malley I999) in which young drug users are now framed as morally deviant customers, who, through their purchasing of illegal commodities (drugs), are complicit in, and hence partially responsible for, organised drug-related crime. The shift in policy discourses about young drug users - from wilful lawbreakers to accomplices in organised drug crime - has not led to legal changes. However, we describe how this novel framing of the issue of youth drug use has been used as a lever for the development of intensified police campaigns specifically targeting drug users and led to the emergence of disciplinary discourses urging drug users to become responsible citizens who, by saying no to drugs, also say no to organised crime. Though reformers have 
also drawn on the framing of drug users as complicit in organised crime to argue for the necessity of 'peace-time' resolutions to the fight against drugs, it remains the case that the discursive coupling of drug use/rs and organised crime has mainly functioned to push Denmark in a more restrictive direction.

In the analysis, we draw on existing research, key government reports, policy papers and content analysis of media accounts of policy and policing developments. The government reports and policy papers were retrieved from open public and ministerial homepages. Media searches have been made in the database Infomedia, which contains all national and local newspapers. Searches have been made especially for drug policy, drugs, youth culture, law enforcement, organised crime, gangs and Christiania from 2000 to 2020 . Media accounts and policy documents have been subjected to content analyses (Braun \& Clarke 2006).

\section{Analytical Framework}

Theoretically, we draw inspiration from critical policy analysis, holding that policies are not straightforward responses to objective problems but rather are active in the creation and shaping of those problems as particular types. More specifically, we draw on Rein and Schön (I993), who argue that policy actors construct and make sense of problematic policy issues through a process of discursive framing defined as 'a way of selecting, organising, interpreting, and making sense of a complex reality to provide guideposts for knowing, analysing, persuading, and acting' (Rein \& Schön I993: I46). Within this framework, the complementary processes of naming and framing not only define what is problematic about an issue, but also suggest what course of action and policies would be appropriate to address the 'problem' (Duke \& Kolind 2020). As Houborg, Søgaard and Mogensen (2020) argue, 'problematisations' of young people, youth culture and drugs have been, and remain, central to much drug policy and practice, but the way they are framed has differed over the years, in turn giving rise to different policies and interventions. Based on existing research, the following two sections outline how the youth drug 'problem' was framed prior to and during the early 2000 s. 


\section{Youth Drug Use as a Social Problem}

Modern Danish drug policy was born in 1955 with the Law on Euphoria-Inducing Substances. The law made possession of illegal drugs for personal consumption an offence (Winsløw I984). In connection with the promulgation of the law, policy-makers stated that penalisation of possession was not meant to criminalise users. Rather, the law was only meant to be a shortcut to criminalise possession with the intent to deal (Houborg, Bjerge \& Frank 2008). During the I960s, new drugs and new groups of users started to appear as part of the youth counter-culture and, as a result, drug use among young people became a very important public issue and policy problem (Houborg \& Vammen 20I 2). In the I960s, I970s and I980s drug use among young people was largely framed as a social problem. During this period, youth drug use was associated with an alternative youth culture that rebelled against established institutions, and with socially disadvantaged living conditions for certain segments of the population (Houborg 2008). The discursive framing of youth drug use as primarily a symptom of various underlying social causes became the foundation of a drug policy that took drug use to be a normal social problem, and one therefore best addressed through social policies and social expertise, including drug prevention and treatment. The aim of this drug policy was to tackle the causes of the problem and to integrate users into society (Houborg 20I0).

The framing of drug use as a social problem also came to influence Danish criminal justice policy on drugs. In 1968, the Danish government proposed an increase in the legal sentencing for professional drug trafficking and drug dealing. Representatives from the police and the public prosecutor were among the strongest supporters of increased criminalisation of professional drug traders. They argued that since Denmark had lower sentences for drug offences than neighbouring Norway and Sweden, international professional drug traders were likely to be attracted to the Danish drug market (Houborg \& Vammen 20I2). To prevent this, supporters argued, a legal correspondence between the Nordic countries was needed (Storgaard 2000). Critics, on the other hand, were concerned that increased criminalisation of professional drug traders would have a spillover effect on the 
sentencing of minor drug offences, which would lead to increased criminalisation and alienation of drug users (Storgaard 2000). Critics also argued that increased sentences for professional drug trading were likely to be counterproductive, in that they would result in rising retail-level prices on cannabis, which would in turn make the Danish cannabis market even more attractive to professional criminals. According to critics, the best way to prevent organised crime was to legalise access to cannabis, as this would make the cannabis market less economically attractive to professional criminals (Houborg \& Vammen 20I2). In June 1969, the parliament reached a compromise. While deciding to amend the Penal Code $(\$$ I9I), increasing the penalty for professional drug dealing and trafficking, a majority of the parliament wanted to avoid further criminalisation of the large number of young people experimenting with drugs, particularly cannabis (Houborg 2010). The parliamentary majority therefore made it a condition of the passing of the Bill that the Attorney General would instruct the police and prosecutors not to charge drug users for possession of illegal drugs for personal use. Such cases should instead be settled with an administrative or court caution (Frank 2008; Houborg, Bjerge \& Frank 2008; Houborg 2010). For drugs other than cannabis, this applied only to first time offences, while for cannabis it also applied to repeat offences. The instruction thus created a de facto decriminalisation of possession of illicit drugs for personal use. In this way, a dual track policy was enacted which not only distinguished between cannabis and other drugs, but which also distinguished between drug suppliers and drug users (Storgaard 2000). While the former were framed as criminals, and therefore to be dealt with via law enforcement, the latter were framed as social clients, whose use of illicit drugs was better addressed through welfare means such as treatment, education, social services and prevention (Houborg, Bjerge \& Frank 2008).

\section{The Young Drug User as a Rational Consumer and Wilful Lawbreaker}

Due to the depenalisation of possession of drugs for personal use, Danish drug policy was for many years considered relatively liberal by international and Nordic standards (Storgaard 2000). 
During the early 2000s, however, this began to change. As with the drug policy reform during the I960s that led to depenalisation, it was drug use among young people, and the discursive framing of this as a particular kind of 'problem', that in 2004 led to a repenalisation of drug possession for personal use (Houborg, Søgaard \& Mogensen 2020).

Debates on drug policy in Denmark in the late I990s and early 2000 sere characterised by intensive discussions about the role of alcohol and drugs in youth culture (Houborg 20I0). The background for this was the publication of comparative survey studies showing that young Danes consumed more alcohol than young people in other European countries, and were among the group of young Europeans with the highest prevalence of cannabis use (Houborg, Søgaard \& Mogensen 2020). This new concern about youth drug use was heightened by intensive media reports about young people's excessive use of ecstasy in nightlife. According to Houborg (2010), two very influential reports - one by the National Board of Health and one by the Chiefs of Police - came to play a key role in a re-framing of the youth drug 'problem' during the early 20oos. Rather than depicting youth drug use as a symptom of social problems and societal changes, and users as subjects in need of help, the two reports instead represented youth drug use as a problem rooted in flawed consumer choices and a lack of moral respect for the law.

The report by the National Board of Health (2000) concluded that a more liberal attitude towards illegal drugs had developed among young people generally, which meant that drug use was becoming an integral part of a new youth culture, especially the urban nightlife party scene. The discursive framing of youth drug use as indicative of a new 'culture of intoxication' (Measham \& Brain 2005) was also evident in the report by the Chiefs of Police (2002). This report described the emergence of new youth culture characterised by individualisation, event culture, party culture, intoxication, experimentation and anomie. As outlined by Houborg (20I0), the report by the Chiefs of Police not only depicted young drug users as economically resourceful (deviant) consumers in a nightlife leisure scene, but also attributed this new drug problem to the policy of depenalisation that had been in force since I969, 
which had allegedly led many young people to believe that use of illegal drugs was not prohibited.

On the basis of this discursive framing, the centre-right government, which had come to power in 200I, formulated a new policy programme in 2003 under the headline 'The Fight against Drugs' (Government 2003a). The policy programme was indicative of a broader shift away from welfarism and explanations that emphasised social determination and towards neoliberalism and neo-conservatism. It articulated the idea that young people's use of drugs was rooted in a new culture of intoxication and essentially a matter of individual consumer choices (Houborg, Søgaard \& Mogensen 2020). Within this policy discourse, young drug users were thus framed as rational and autonomous consumers who deliberately chose to break the law. Against this background, the white paper emphasised that it was important to send a 'clear signal' to young drug users that this kind of behaviour was unacceptable and would have legal consequences. Couched in the rhetoric of 'zero tolerance', 'deterrence' and 'respect for the law' (Frank 2008; Houborg, Søgaard \& Mogensen 2020), the new drug policy led to a legislative amendment in 2004 that reintroduced penalties for all personal possession of illicit drugs. The government hoped that the repenalisation of possession for personal use would deter young consumers from exercising their freedom in an irresponsible and deviant way, and instead foster a new moral order characterised by respect for the law (Houborg 20I0). The shift towards an understanding of young drug users as individualised and rational consumers was also evident in subsequent parliamentary debates, which in 2007 led to an increase of the fines for possession of illicit drugs. On this issue, Karsten Nonbo from the liberal government party Venstre said: 'We are tightening the penalty for possession of euphoric drugs. We are doing this because we have too many so-called "rich kids", that is, we have too many people who go to discos, those who have their pockets full of money' (Folketingstidende 2006/07).

The neo-conservative framing of youth drug use as a consumer- and choice-based moral failure has played a key role in the production of young recreational drug users as objects of a zero-tolerance governance approach in Denmark. 


\section{The Drug User as an Indirect Accomplice in Organised Crime}

While the early 2000 s saw a move towards a neoliberal and more moralistic point of view, where the use of illicit drugs was explained in terms of consumer-based wilful transgressions in a new kind of risk environment (i.e. nightlife), during the mid and late 2000 s a new discursive framing of youth drug use started to gain prominence. In the following, we outline how recent Danish drug control policy debates have become increasingly dominated by a discursive framing that depicts young and recreational drug users as complicit in organised crime. Linked to this shift is a new moral configuration of young drug users, as well as the deployment of police campaigns specifically aimed at targeting young and recreational drug users.

The present day discursive framing of young and recreational drug users as complicit in organised crime is part of a longer process. In I982, the Copenhagen Police Department released a report describing how outlaw bikers were involved in the cannabis market in the Free Town of Christiania, Copenhagen (Copenhagen Police 1982). Based on their observations at Christiania, the police gave voice to the perspective that the selling of cannabis was becoming more professionally organised, and that drug trading was the key economic basis of outlaw biker groups. These ideas gained prominence in public debates during the I990s, especially during and after the 'Big Nordic Biker War' (Strand 20II). In 2003, when the centre-right government launched its new drug policy, The Fight against Drugs, it highlighted criminalisation and intensified policing as the best ways to combat cannabis-related organised crime. As part of its new tough-on-drugs policy, the government made the dissolution of the cannabis trade in Christiania - the biggest open drug market in Scandinavia - a key priority (Government 2003a). In the policy paper, the government repeated the argument that close links existed between the cannabis trade at Christiania and organised crime. The Government also emphasised that intensified policing was important as a means of combatting the organised crime groups believed to be responsible for the cannabis trade at Christiania. The policy paper, and a later action plan (Government $2003 \mathrm{~b}$ ), specified that the intensified 
police approach would involve I) an increased police presence, with more raids, drug seizures and arrests of sellers and backers, and 2) a physical removal of sales stalls in Pusher street, the main cannabis sales area at Christiania. Furthermore, the action plan stated 3) that the police should increase their targeting of 'the recipients' of cannabis (i.e., the users) at Christiania, as this would make it more difficult for drug traders to sell their commodities (Government 2003 b: 8999). The action plan outlined that the latter process should involve increased use of stop and search methods, sniffer dogs and traffic stops to check if potential customers going to or coming from Christiania were in possession of cannabis or driving under the influence of cannabis.

In the media, the Minister of Justice, Lene Espersen, explained that the police had been instructed to actively target the 'buyers' frequenting Pusher street in Christiania because this would 'result in a situation where the buyers will no longer find it attractive to go to Christiania to source hash' (Berlingske Tidende 2003a). Similar to the debates about young peoples' use of ecstasy and cocaine in nightlife, the Minister of Justice thus invoked a notion of the cannabis user as a rational actor who could be deterred into conformity. However, rather than describing the rational cannabis user as a consumer, as had been the case in debates regarding the much talked about new youth nightlife culture, in policy documents and in the debates addressing the situation at Christiania, cannabis users were now described as 'recipients of cannabis', 'buyers' and 'customers', and as the 'customer-base' for criminals (Berlingske Tidende 2003a; DR.DK 2003; Jyllands-Posten 2003a). This change of vocabulary was indicative of the gradual emergence of a new dominant discourse in which drug users were increasingly framed as market actors, whose 'demand' for drugs constituted the economic basis for the criminal drug trade: 'Hash customers - all the more or less ordinary and decent people, including tourists, who are the basis for Pusher street's existence - can look forward to a more tough police approach' (Berlingske Tidende 2003 b).

While Danish drug policy had traditionally rested on a dual track policy that distinguished between drug suppliers and drug users (Storgaard 2000), the new policy discourse not only 
dissolved this distinction, but also framed drug users, in their capacity as economic customers, as (indirectly) complicit in drug-related organised crime. The emerging framing of youth and recreational drug use as the economic driver underpinning criminal drug trading was not only evident in discursive reconfigurations of 'drug users' into 'drug buyers' and 'drug use' into 'drug demand'. It was also evident in the fact that the tough-oncrime rhetoric, such as the terms 'to stress' and 'stress strategies', which had hitherto been used to describe the 'pulling lever tactics' (Kennedy I997) used by Danish police to make life difficult for outlaw bikers, gangs and drug sellers (Volquartzen 2009; Strand 20II; Rowe \& Søgaard 2020), was now also being used by police to describe their approach to cannabis users at Christiania: 'Now we have been stressing the sellers and the buyers for some time. We will continue doing so, but at some point, we will take it to the next level. We will come in hard and demolish Pusher street when it suits us' (Copenhagen Police Chief Inspector in JyllandsPosten, 2003a).

In the months following the launch of the government's new Christiania strategy, the police intensified their targeting of drug users frequenting the cannabis market at Christiania. As part of the new buyer-directed 'stress strategy' (Berlingske Tidende $2003 \mathrm{C}$ ), in the first month, the police searched 459 persons and 2448 cars. Two hundred and forty-eight persons were fined for being in possession of illegal substances, and 557 were fined for traffic violations in and around the Christiania area (JyllandsPosten 2003 b). In 2004, the police launched a major crackdown, during which bulldozers and armed police entered Christiania and removed the stalls where cannabis was being sold. Fifty cannabis dealers and 'security guards' were arrested (Frank 2008; Moeller 20I 8 ). While the police had hoped that this crackdown would effectively put an end to the Christiania cannabis market, history has shown that this was not the case.

Over the following years, however, the discursive framing of young and recreational drug users as the economic basis for criminal and organised drug trading grew in prominence. Not only did this discursive framing spread beyond the Copenhagen context, it also came to include other drug users, such as recreational users of cocaine, ecstasy and amphetamine. This development was part 
of a broader process where policies and police approaches that were originally developed to target the specific cannabis market at Christiania spread to other areas and domains. As an example of this, Moeller (2020) has documented how, since 2003 - the year the government launched its first Fight against Drugs-policy (Government 2003a) - there has been a remarkable quantitative increase in the enforcement intensity of the Law on EuphoriaInducing Substances. While the period between 2004 and 2010 was characterised by a quantitative increase in enforcement intensity, stemming mostly from crackdowns on cannabis retail sales in Copenhagen, from $20 \mathrm{II}$ to $20 \mathrm{I} 7$ police districts outside of Copenhagen came to drive the overall increase. This development coincided with the launch of the government's second drug action plan in 2010 - The Fight against Drugs II (Government 20IO). While this action plan emphasised the importance of maintaining and increasing the intensity of drug law enforcement against possession offences and against organised drug trading, it no longer contained references to the specific cannabis market in Copenhagen (Moeller 2020). Across the different police districts in Denmark, the average increase in reported Law on EuphoriaInducing Substances offences rose by $42 \%$ from 2007 to 2017 , with some provincial police districts, such as Mid- and West Sealand Police, and North Jutland Police, registering increases of I $27 \%$ and $122 \%$ respectively (Moeller 2020).

Both in Copenhagen and elsewhere, police have often drawn on discourses that frame young and recreational drug users as the economic basis for organised drug trading to publicly justify their intensified targeting of drug users:

We target those who want to buy hash, because we want to combat the criminal backers, by making it unsafe for their buyers, which means that they lose their customer base.

(Head of Task Force Pusher Street in DR.DK 20I2)

[We target people who buy cannabis and other drugs from mobile dealers] because we want to get to the root of the problem. When there are buyers, there will also be sellers, and while the police make a great effort to combat the organised drug trade, it is a fundamental problem that there is still a demand.

(Police Commissioner in Mid- and West Jutland Police 2019) 


\section{A New Moral Configuration of the Drug User}

The intensified policing of drug users as a means of combatting organised crime has been coupled with a new moral configuration of young and recreational drug users. During the 2000s, many Danish cities experienced a growth in gang conflicts and shootings, resulting in an intensified media focus on the linkages between drugs and organised crime (Houborg \& Enghoff 20I8). In this climate of heightened public concern about gang-related crime and violence, Danish police became strong public promoters of a moralistic discourse, in which young and recreational users of cannabis and other drugs were blamed for the ongoing gang conflicts. As illustrated in the above, drug users are sometimes identified as the 'root of the [gang] problem'. In 20I I, for instance, the Chief of Danish Police, Jens Henrik Højbjerg, made a public appeal in which he emphasised that the authorities could not by themselves combat the crime and violence committed by outlaw bikers and gangs. Ordinary Danes also needed to take responsibility.

If we all showed responsibility and didn't allow ourselves [to] be tempted, things would be very different (...). Citizens should stop buying stolen goods, and they should not buy amphetamine or cocaine on a night out at the weekend (...). Think about what kind of people you are supporting when buying stolen goods or drugs.

(TV2 Lorry 20II)

In recent years, the morally condemnatory tone and the argument that 'if you choose to buy illegal drugs you support criminal gangs' have recurred consistently in public statements by the police, as the following quotes illustrate:

Those who buy hash at Pusher street support organised crime and thereby the criminals, who repeatedly defend their crime with violence against the police.

(Chief Police Inspector, Copenhagen Police, in DR.DK 20I8)

People just need to realise that when you buy hard drugs, ultimately you are underpinning organised crime in one way or the other.

(Police Inspector, Mid- and West Jutland Police, in TV Midtvest.dk 20I9) 
By buying hash from these people you are underpinning the gangs in Esbjerg, and thereby also the continuation of the gang conflict.

(Vice Police Inspector, South Jutland Police, JydskeVestkysten 2020)

While leading politicians and the police have been the key moral entrepreneurs promoting condemnatory discourses that attribute responsibility for gang criminality and violence onto drug users, such discourses are today also replicated in the broader media, sometimes under headlines such as 'Hash-smokers support gangs' (B.T. 2009) or 'The coke-sniffing upper class has a responsibility for gang crime' (Information 20I9). In such accounts, young and middle- and upper-class drug users are sometimes depicted as hypocrites who care much about how their actions impact on the climate but little about how their drug habits supposedly feed gang violence (see Information 2019).

The above illustrates how recent drug control policy debates in Denmark have involved a strategic mobilisation of morality (O’Malley I999) encapsulated in a discourse where the young and recreational drug user is reconfigured from a consumer and wilful law-breaker to a customer and indirect accomplice in organised drug crime and related violence. Hence, drug use is no longer framed merely as an individualised moral failure to comply with the law, but increasingly also as a moral failure to be a responsible citizen. From this perspective, drug use is not seen as a victimless crime. Rather, it is represented as a key driver of gang-related violence. By implication, drug users are depicted as hedonistic and selfish people who 'support' criminals and who do not care about how their practices are indirectly exposing others to risks - i.e., the potential victims of drug-related violence. Moralisation against drug users is thus deliberately mobilised not only to justify police use of user-directed punitive approaches, but also as a governmental strategy to 'responsibilise' (Garland I996) young and middle-class people. This is carried out by communicating the message that apparently harmless drug use has dire consequences for others in the drug supply chain, and that, as moral citizens, would-be users therefore ought to demonstrate a societal responsibility and care for the wellbeing of others by choosing to abstain from buying illicit drugs. 


\section{Gang Talk and Cannabis Legalisation}

In Denmark, the discursive framing of young and recreational drug users as the economic basis for criminal drug trading has predominantly been used to promote user-centred punitive approaches. In the following, however, we briefly outline how this framing has also been used in recent years by reformers to argue for the necessity of a legalised cannabis market.

While the early 2000 s was characterised by relative political consensus, both at municipal and national levels, about the usefulness of a punitive zero-tolerance approach, 2009 marked a turning point in cannabis policy debates (Houborg \& Enghoff 20I8). During 2008 and 2009, the gang-related violence in Copenhagen reached a peak, and its effects on the lives of ordinary citizens were widely reported by the media. As part of his campaign for the 2009 municipal election, the incumbent mayor of Copenhagen, Frank Jensen, from the Social Democrats, therefore proposed introducing a three-year trial period where all cannabis users above I 8 years of age should be legally able to purchase cannabis from shops in Copenhagen run by the state (Politiken 2009). The Liberal-Conservative government, however, immediately rejected the proposal. Nevertheless, from 2009 onwards, references to the gang conflicts have been central in political discussions about cannabis and the possibilities for legalisation (Houborg \& Enghoff 2018). Representatives of the Copenhagen municipality have played a key role in these debates. As outlined by Nygaard-Christensen and Frank (2019), in January 2017, the Social Democrats in Copenhagen argued for a legalisation trial by suggesting that legalisation would 'remove some of the economy of the criminal gangs who today profit from cannabis being illegal'. This line of argument has also been adopted by national politicians. In 2016, the parliamentary party Radikale Venstre noted the following in their proposal for a trial legalisation of cannabis:

The illegal cannabis sale at Christiania and elsewhere is controlled by organized criminals and gangs (...). Therefore, it is necessary to rethink and explore the possibilities for a responsible and controlled way of legalizing cannabis, so that cannabis sale does not continue to remain a lucrative business for organized criminals.

(Quoted in Nygaard-Christensen \& Frank 2019:6) 
As outlined earlier, in the policy debates that in I969 led to an increase in the legal sentencing for professional drug trading, critics had warned that increased criminalisation was likely to result in rising retail-level prices on cannabis, thereby fertilising the ground for a growth in organised drug trading (Houborg \& Vammen 20I2). In the 20IOs, reformers argued that the turn towards more punitive policies, both in 1969 and especially after 2004, had indeed come to act as a criminogenic driver resulting in increased gang activities. Coming full circle, reformers today argue that legalisation of cannabis is the only way to prevent the continuous popular demand for cannabis, and its economic revenue, ending up in the hands of organised criminals. Importantly, advocates arguing for the need for cannabis policy reform have not challenged the discursive framing of drug users as market customers whose purchasing practices feed organised crime. On the contrary, their argument for cannabis legalisation seems to reinforce this discourse. The solution reformers point to, however, is very different from the punitive one that dominates today. While the cannabis reform movement has gained momentum, in the Danish parliament there is still an overwhelming majority opposed to legalisation or decriminalisation (Nygaard-Christensen \& Frank 20I9).

\section{Conclusion}

In this chapter, we have outlined how changes in Danish drug control policy have been underpinned by discursive changes in the way youth and recreational drug use is framed in government reports, policy documents and the media. While previous studies have described how the discursive framing of youth drug use as a deviant consumer choice set within a nightlife context became a catalyst for more restrictive policies in Denmark during the early 2000 (Houborg 2008; Houborg 2010; Houborg, Søgaard \& Mogensen 2020), in this chapter we have analysed how recent decades have seen the emergence of a new discursive and politically potent framing of youth and recreational drug use as feeding organised crime. While this discursive shift has not led to legal changes, it has functioned as the foundation for an increase in the intensity of drug law enforcement, often used specifically to target and 'stress' drug users. Within this new discourse, intensified police targeting of drug users is justified as a means of combatting 
organised crime, and young and recreational drug users are morally configured as selfish persons who allegedly do not care about how their drug habits feed gang conflicts and thus expose others to risk and harm. In this way, recent years have seen an intensification of the moral condemnation of young drug users in Denmark.

Similar tendencies today characterise drug policy debates in countries such as England and Sweden. In England, the National Crime Agency launched a campaign in 2015 entitled '\#everylinecounts', which aimed to raise awareness among middle-class individuals about how their seemingly harmless drug use had dire consequences for others in the drug supply chain, for local communities and for the environment (National Crime Agency 2015 ). The campaign not only attributed blame for the harm done by the drug trade onto users, it also sought to responsibilise young and recreational users through slogans such as 'Your choices can change everything'. In the UK, this discourse has been promoted by government representatives and leading politicians. In 2018, the Mayor of London, Sadiq Khan (The Guardian 2018a), the most senior UK police chief, Cressida Dick (The Guardian 20I 8b), and the British Justice Secretary, David Gauke (Independent 20I 8), all publicly argued that individuals who consume cocaine at dinner parties are to blame for street violence in cities across the UK. More recently, UK politicians and the media have also singled out middle-class cocaine users, often depicted as selfish individuals who lead privileged lives, as the key people responsible for the emergence of highly exploitative criminal county-line supply models (Spicer 202I). In a similar vein, Swedish Prime Minister Stefan Löfven recently argued that middle-class drug users in the more affluent parts of Swedish cities are partly to blame for the gang-related violence in the more marginalised neighbourhoods (Expressen 2019).

The above illustrates how recent drug control policy debates in Denmark mirror developments in some other European countries, where 'gang-talk' has taken centre stage in arguments for more punitive approaches (see Spicer 202I). However, a notable difference exists. While the framing of drug users as complicit in gang crime in the UK has mainly focused on cocaine users, in Denmark (and in Sweden) today, this framing also dominates discourses about cannabis users. So, while Canada, Uruguay and several US 
states have legalised cannabis, and many European countries have implemented or are considering decriminalisation of cannabis as an option, Denmark is one of the few Western countries that is going in the opposite direction, away from a lenient decriminalisation policy and towards a more restrictive approach (Houborg, Søgaard \& Mogensen 2020; Moeller 2020). As demonstrated in this chapter, discursive linkages between cannabis use/rs and concerns about organised crime have played a key role in this process.

As our analysis has shown, Danish police have, at times, described the intensified policing of drug buyers as a way to address the 'root' of the drug market problem. Contrary to this, Spicer (202I) has argued that contemporary discourses allocating blame and responsibility for the harms of the drug trade onto drug users represents a form of surface scapegoating that functions to divert attention away from the underlying structural and social conditions that drive drug markets. In Denmark, it remains the case that most street gangs are composed of socio-economically marginalised men (Pedersen 20I4), and that men of lower socioeconomic status are also the primary users of cannabis (Bloomfield, Elmeland \& Villumsen 20I3) and the demographic most likely to be targeted by police for possession of illegal drugs (Houborg, Kammersgaard \& Pedersen 2016). Yet, in Danish drug control policy debates on young peoples' use of drugs, socio-economic factors and issues related to social marginalisation are increasingly silenced, and instead replaced by a focus on morality and individualised choices.

\section{References}

Berlingske Tidende. (2003a). Fristanden: Pusherstreet skal bekæmpes. Berlingske Tidende, 06.05.2003.

Berlingske Tidende. (2003 b). Skrap kurs mod Christiania og hashkunderne. Berlingske Tidende, 06.05.2003.

Berlingske Tidende. (2003 c). Hashhandlere tager det med ro. Berlingske Tidende, 06.05.2003.

Bloomfield, K., Elmeland, K. \& Villumsen, S. (2013). Rusmidler $i$ Danmark - forbrug, holdninger og livsstil. Aarhus: Center for Rusmiddelforskning, Aarhus Universitet. 
Braun, V. \& Clarke, V. (2006). Using thematic analysis in psychology. Qualitative Research in Psychology, 3(2), 77-IоI.

B.T. (2009). Hashrygere støtter bander. B.T., 27.10.2009.

Chiefs of Police [Politimesterforeningen]. (2002). Ecstacy-rapport. København: Rigspolitiet.

Copenhagen Police [Københavns Politi]. (1982). Uropatruljen, Redegørelse I982, bilag XIII.

DR.DK. (2003). Hashsalget på Christiania skal væk. DR.DK, 06.05 .2003 .

DR.DK. (20I2). Politiet jagter hashkøberne på Christiania. DR.DK, 07.09 .2012 .

DR.DK. (20I8). Betjente fandt pistol ved aktion mod Pusher Street. DR.DK, 28.03.20I8.

Duke, K. \& Kolind, T. (2020). Framing and reframing drug 'problems' in prison spaces and populations. In S. MacGregor \& B. Thom (Eds.), Risk and substance use framing dangerous people and dangerous places (pp. I62-182). London: Routledge.

Expressen. (20I9). Löfven: 'Rikas drogvanor göder gängkriminaliteten'. Expressen, I3.08.20I9.

Frank, V. A. (2008). Danish drug policy - Shifting from liberalism to repression. Drugs and Alcohol Today, 8(2), 26-33.

Folketingstidende. (2006/07) L 20I, Appendix FF 5673. https:// www.folketingstidende.dk/samling/2006r/lovforslag/L20 I/index .htm.

Garland, D. (I996). The limits of the sovereign state: Strategies of crime control in contemporary society. The British Journal of Criminology, 36(4), 445-47 I.

Government [Regeringen]. (2003a). Kampen mod narko: Handlingsplan mod narkotikamisbrug. København: Indenrigs- og Sundhedsministeriet.

Government [Regeringen]. (2003 b). Redegørelse af 7/5 o3 om Christiania. (Redegørelse nr. R I2). København: Forsvarministeren. 
Government [Regeringen]. (2010). Kampen mod narko II-handling splan mod narkotikamisbrug. København: Statens Informationstjeneste.

Houborg, E. (2008). Youth, drugs and the welfare state. In V. A. Frank, B. Bjerge, B. \& E. Houborg (Eds.), Drug policy. History, theory and consequences (pp. I $8 \mathrm{I}-208$ ). Aarhus: Aarhus University Press.

Houborg, E. (2010). Control and welfare in Danish drug policy. Journal of Drug Issues, 4o(4), 783-804.

Houborg, E. \& Bjerge, B. (20I I). Drug policy, control and welfare. Drugs: Education, Prevention and Policy, I8(I), I6-23.

Houborg, E. \& Enghoff, O. (2018). Cannabis in Danish newspapers. Tidsskrift for Forskning i Sygdom og Samfund, 28, I73-205.

Houborg, E. \& Vammen, K. S. (2012). Hashbekymringen I965I969. In Dahl, H. V. \& Frank, V. A. (Eds.), Cannabis. Forbrug, interventioner og marked i Danmark (pp. 23-49). Aarhus: Aarhus Universitetsforlag.

Houborg, E., Bjerge, B. \& Frank, V. A. (2008). Introduction: Danish drug policy - history, theory and the international framework. In V. A. Frank, B. Bjerge, B. \& E. Houborg (Eds.), Drug policy: History, theory and consequences (pp. 9-32). Aarhus: Aarhus University Press.

Houborg, E., Kammersgaard, T. \& Pedersen, M. M. (2016). Drug policing in four Danish police districts. Police Practice and Research, I7(4), 329-340.

Houborg, E., Søgaard, T. F. \& Mogensen, S. (2020). Making up a new drug user from depenalization to repenalisation of drug users in Denmark. International Journal on Drug Policy, 80, I-9.

Independent. (2018). Middle class people taking cocaine at dinner parties should feel 'guilty and responsible' over street stabbings, says justice secretary. Independent, 27.05.20I 8 .

Information. (2019). Den cokesniffende overklasse har et medansvar for bandekriminaliteten. Information, I9.08.20I9. 
JydskeVestkysten. (2020). Bøderegn over tusindevis af hashkøbere i Esbjerg: Afsløret af sms-beskeder. JydskeVestkysten, 04.02.2020.

Jyllands-Posten. (2003a). Christiania: Politiet vil tage Christiania med storm. Jyllands-Posten, 30.07.2003.

Jyllands-Posten. (2003 b). Christiania: Politi: Christiania-indsats virker. Jyllands-Posten, I 2.06.2003.

Kennedy, D. M. (I997). Pulling levers: Chronic offenders, highcrime settings, and a theory of prevention. Valparaiso University Law Review, 3I, 449-484.

Measham, F. \& Brain, K. (2005). 'Binge' drinking, British alcohol policy and the new culture of intoxication. Crime, Media, Culture: An International Journal, I(3), 262-283.

Mid- and West Jutland Police [Midt- og Vestjyllands Politi]. (20I9). Flere hundrede købere bliver nu sigtet i narkosag fra Skive [Press Release]. I3.II.20I9.

Moeller, K. (20I 8). Video-recorded retail cannabis trades in a lowrisk marketplace: Trade value and temporal patterns. Journal of Research in Crime and Delinquency, 55(I), I03-I24.

Moeller, K. (2020). Enforcement intensity in Danish drug control, I996-20I7. European Journal on Criminal Policy and Research, online before print.

National Board of Health [Sundhedsstyrelsen]. (2000). Unges brug af illegale rusmidler - en kvalitativ undersøgelse. København: Sundhedsstyrelsen.

National Crime Agency. (20I 5). Every line counts. Retrieved 22.06.2020. https://www.contentod.co.uk/every-line-counts.

Nygaard-Christensen, M. \& Frank, V. A. (2019). Cannabis regulation in Europe: Country report Denmark. Aarhus: Center for Rusmiddelforskning \& Amsterdam: The Transnational Institute.

O’Malley, P. (I999). Consuming risks: Harm minimization and the government of 'drug-users'. In R. Smandych (Ed.), Governable places: Readings on governmentality and crime control (pp. I9I-2 I4). Ashgate: Aldershot. 
Pedersen, M. L. (20I4). Gang joining in Denmark: Prevalence and correlates of street gang membership. Journal of Scandinavian Studies in Criminology and Crime Prevention, I 5(I), 55-72.

Politiken. (2009). Frank J. vil have landsdækkende hashforsøg. Politiken, 24.09.2009.

Rein, M. \& Schön, D. (1993). Reframing policy discourse. In F. Fischer \& J. Forester (Eds.), The argumentative turn in policy analysis and planning (pp. I45-166). London: UCL Press.

Rowe, M. \& Søgaard, T. F. (2020). 'Playing the man, not the ball': Targeting organised criminals, intelligence and the problems with pulling levers. Policing and Society, 30(2), I20-I35.

Spicer, J. (202I). Between gang talk and prohibition: The transfer of blame for county lines. International Journal of Drug Policy, 87, I-8.

Storgaard, L. L. (2000). Konstruktionen af dansk narkotika Kontrolpolitik siden I965. København: Jurist og Økonomforbundet.

Strand, F. (20I I). Efterforskningens anatomi. Kriminalpolitiet I 863-2007. København: Jurist- og Økonomforbundets Forlag.

The Guardian. (2018a). Middle-class cocaine use fuels London's rising violence, says Sadiq Khan. The Guardian, 27.07.20I 8 .

The Guardian. (20I8b). Middle-class cocaine users are hypocrites, says Met chief. The Guardian, 31.07.201 8.

TV Midtvest.dk. (20I9). Misbrugsbehandler: Kokain er blevet lige så almindeligt som en fyraftensøl. Tv Midtvest.dk, I3.I I.20I9.

TV2 Lorry. (20I I). Politichef giver opsang til danskerne. TV2 Lorry, I4.04.20II.

Volquartzen, M. (2009). I tryghedens navn - politiets rolle $i$ det senmoderne samfund. Frederiksberg: Frydenlund og CeRePo.

Winsløw, J. (1984). Narreskibet: en rejse i stofmisbrugerens selskab fra centrum til periferi af det danske samfund. Holte: SOCPOL. 